mgr inż. Anna Dziechciarz ${ }^{1}$

mł. bryg. inż. Piotr Lesiak ${ }^{1}$

inż. Damian Bąk ${ }^{1}$

Przyjęty/Accepted/Принята: 11.03.2015;

Zrecenzowany/Reviewed/Рецензирована: 23.05.2015;

Opublikowany/Published/Опубликована: 30.06.2015;

\title{
Analiza możliwości wykorzystania programu RizEx-2 w symulacji przebiegu zdarzenia awaryjnego na przykładzie wybuchu gazu w Port Hudson ${ }^{2}$
}

\author{
An Analysis of the Potential for Using RizEx-2 Software to Simulate Emergency \\ Events such as the Gas Explosion in Port Hudson
}

\author{
Анализ возможностей использования программы RizEx-2 для симуляции хода \\ аварии на примере взрыва газа в Порт-Хадсон
}

\begin{abstract}
A BS TRAKT
Cel: Głównym celem artykułu jest analiza możliwości odtworzenia sytuacji awaryjnej z wykorzystaniem programu RizEx-2. Wprowadzenie: W 1970 roku w miejscowości Port Hudson w stanie Missouri najprawdopodobniej doszło do rzadko spotykanego zjawiska, jakim jest detonacja gazu w przestrzeni nieograniczonej. W wyniku ekskawacji doszło do uszkodzenia rurociągu przesyłowego z propanem, co doprowadziło do uwolnienia około $120 \mathrm{~m}^{3}$ ciekłego gazu. Opis wypadku oraz analiza możliwości jego rozwoju zostały opisane w raporcie wykonanym na zlecenie Narodowej Rady Bezpieczeństwa Transportu przez Amerykański Urząd Górnictwa. W raporcie specjalny nacisk położono na możliwe źródła zapłonu, obszar rozprzestrzenienia propanu oraz analizę rozmiaru zniszczeń fali uderzeniowej.

Metodologia: Dokonano analizy możliwości odtworzenia sytuacji awaryjnej z wykorzystaniem programu RizEx-2 na podstawie zdarzenia, jakie miało miejsce w roku 1970 w Port Hudson (USA), w celu zbadania zasadności użycia tego programu do przeprowadzania oceny skutków wypadków z udziałem gazów wybuchowych. W pierwszej części artykułu opisany został raport ze zdarzenia przygotowanego zaraz po katastrofie. Następnie dokonano symulacji/odtworzenia wydarzeń przy pomocy programu obliczeniowego RizEx-2. Ostatecznie stworzono analizę porównawczą wyników uzyskanych w programie RizEx-2 oraz rezultatów przedstawionych w raporcie. Do wykonania symulacji zdarzenia w Port Hudson skorzystano z trzech modułów programu: Dispersion Gaussian Model - Neutral Gas, Formation of Explosion-Hazardous Cloud, Explosion. Aby uzyskać lepszy obraz tego, jak program odzwierciedli zdarzenia w Port Hudson, założono wystąpienie takich samych warunków pogodowych oraz prędkości wycieku propanu, jakie zostały podane w raporcie. Rozpatrzono dwa scenariusze rozwoju wydarzeń. W scenariuszu 1 przyjęto prędkość wiatru równą $3 \mathrm{~m} / \mathrm{s}$, a w scenariuszu 2 wynosiła ona $4 \mathrm{~m} / \mathrm{s}$.

Wnioski: Na podstawie przeprowadzonej analizy wnioskuje się, że program RizEx-2 może stanowić cenne narzędzie w analizie awarii z udziałem gazociągów oraz ich następstw. Jednakże należy uwzględnić ograniczenia programu i nie traktować otrzymanych wyników, jako ostatecznych, a jako pomoc w interpretacji analizowanych zdarzeń. Dane wykorzystywane do obliczeń powinny być uzyskiwane przede wszystkim na podstawie dochodzenia ze zdarzenia, a wyniki programu zawsze ewaluowane w odniesieniu do rzeczywistych skutków.
\end{abstract}

Słowa kluczowe: wybuch gazu, RizEx-2, symulacja zdarzenia awaryjnego, gaz wybuchowy

Typ artykułu: studium przypadku - analiza zdarzeń rzeczywistych

\footnotetext{
Centrum Naukowo-Badawcze Ochrony Przeciwpożarowej - Państwowy Instytut Badawczy, Józefów / Scientific and Research Centre for Fire Protection National Research Institute, Poland; adziechciarz@cnbop.pl;

2 Wkład merytoryczny w powstanie artykułu / Percentage contribution: A. Dziechciarz - 50\%, P. Lesiak - 30\%, D. Bąk - 20\%;
} 


\section{A BSTRACT}

Aim: The main focus of this paper is to analyze the potential of constructing a simulation scenario, which can reproduce an emergency situation, using a software system RizEx-2.

Introduction: During 1970, in Port Hudson, Missouri a rare incident occurred in the form of an unconfined gas explosion. During excavation work, a pipeline transporting propane was damaged, which caused an accidental release of approximately $120 \mathrm{~m}^{3}$ of liquefied gas. The incident description and hypothetical analysis of potential developments were presented in a report written by the United States Bureau of Mines at the behest of the National Transportation Safety Board. The report placed a special emphasis on possible ignition sources, the dispersion of flammable vapours and the analysis of blast damage.

Methodology: An analysis was performed on the possibility of recreating an emergency scenario with the aid of RizEx-2 software, based on the incident in 1970 at Port Hudson (USA), in order to examine the appropriateness of this programme to perform assessments of consequences arising from incidents involving explosive gases. The first part of this article describes the incident report produced immediately after the accident. Next, a simulation model was constructed of events, with the aid of a software programme RizEx-2. Finally, an analysis was performed, which compared results produced by the software programme against outcomes revealed by the report. The simulation of events at Port Hudson utilised three programme modules: Gaussian Dispersion Model-Neutral Gas, Formation of Explosion-Hazardous Cloud and Explosion. To get a better picture of how the programme mirrors actual events in Port Hudson, the same incident circumstances were created, including weather conditions as well as the speed of propane leakage identified in the report. From this two incident development scenarios were examined. In the first it was assumed that the wind speed was at $3 \mathrm{~m} / \mathrm{s}$ and the second was at $4 \mathrm{~m} / \mathrm{s}$.

Conclusion: On the basis of analysis performed, it is concluded that the programme RizEx-2 can be a valuable tool in the evaluation of incidents involving pipelines and their consequences. However, the limitations of the programme should be taken into account and results should not be viewed as final, but used as an aid in the interpretation of studied events. The data used in calculations should be, primarily, based on details from the investigation of events, and the results from the programme should be always evaluated in relation to actual outcomes.

Keywords: gas explosion, RizEx-2, simulation of an emergency event, explosive gas

Type of article: case study - analysis of actual events

\section{АННОТАЦИЯ}

Цель: Главной целью статьи является анализ возможности воссоздания аварийной ситуации с использованием программы RizEx-2.

Введение: В 1970 г. в городе Порт-Хадсон в штате Миссури, скорее всего, произошло редкое явление - детонация газа в неограниченном пространстве. В ходе добычи был поврежден трубопровод для транспортировки пропана. Вследствие этого вытекло около $120 \mathrm{~m}^{3}$ жидкого газа. Описание аварии и анализ возможностей её развития описаны в отчёте, сделанном по поручению Национального Совета По Безопасности Транспортировки Американским Горным Управлением. В этом отчёте особенное внимание было уделено возможным источникам воспламенения, территории распространения пропана и анализу размера разрушений, вызванных ударной волной.

Методология: Совершен анализ возможности воссоздания обстоятельств аварийной ситуации с использованием программы RizEx-2 на основе аварии, которая случилась в 1970 г. в Порт-Хадсон (США), для того чтобы изучить вопрос о целесообразности использования этой программы и для проведения оценки последствий аварий, связанных с взрывоопасными газами. В первой части статьи был описан отчёт об инциденте, составленный сразу после аварии. Далее была сделана симуляция событий с помощью расчётной программы RizEx-2. В конце был разработан сравнительный анализ результатов, полученных в программе RizEx-2, и результатов, представленных в отчёте. Для выполнения симуляции аварии в Порт Хадсон были использованы три модуля программы: Dispersion Gaussian Model - Neutral Gas, Formation of Explosion-Hazardous Cloud, Explosion. Чтобы получить лучшую картину события в данной программе, были приняты те погодные условия и скорость утечки попрана, которые поданы в отчёте. Рассмотрены два сценария развития событий. В 1 сценарии принята скорость ветра равна $3 \mathrm{~m} / \mathrm{c}$, а 2 сценарии $-4 \mathrm{~m} / \mathrm{c}$.

Выводы: На основе проведенного анализа можно прийти к выводу, что программа RizEx-2 может представлять собой ценный инструмент при анализе аварии с участием газопроводов и их последствий. Однако, следует принимать во внимание ограничения программы и не считать полученных результатов окончательными, а как помощь при интерпретации анализируемых событий. Данные, используемые для вычислений, должны быть, прежде всего, полученные на основе расследования инцидента, а результаты программы всегда следует оценивать по отношению к реальным последствиям.

Ключевые слова: взрыв газа, RizEx-2, симуляция аварии, взрывоопасный газ

Вид статьи: тематическое исследование - анализ реальных событий

\section{Wprowadzenie}

Transport gazów palnych wiąże się z dużym ryzykiem awarii z uwagi na właściwości fizyczne transportowanego medium, takie jak np. niska temperatura wrzenia, palność, tworzenie mieszanin palnych z powietrzem w krótkim czasie. W samych Stanach Zjednoczonych w latach 1994-2014 takich wypadków było 1238, czyli średnio 62 wypadki rocznie. Poniżej na ryc. 1 przedstawiono wykres obrazujący liczbę zdarzeń awaryjnych rurociągów w Stanach Zjednoczonych. (U.S. Department of Transportation Pipeline and Hazardous Materials Safety Administration, 2015). 


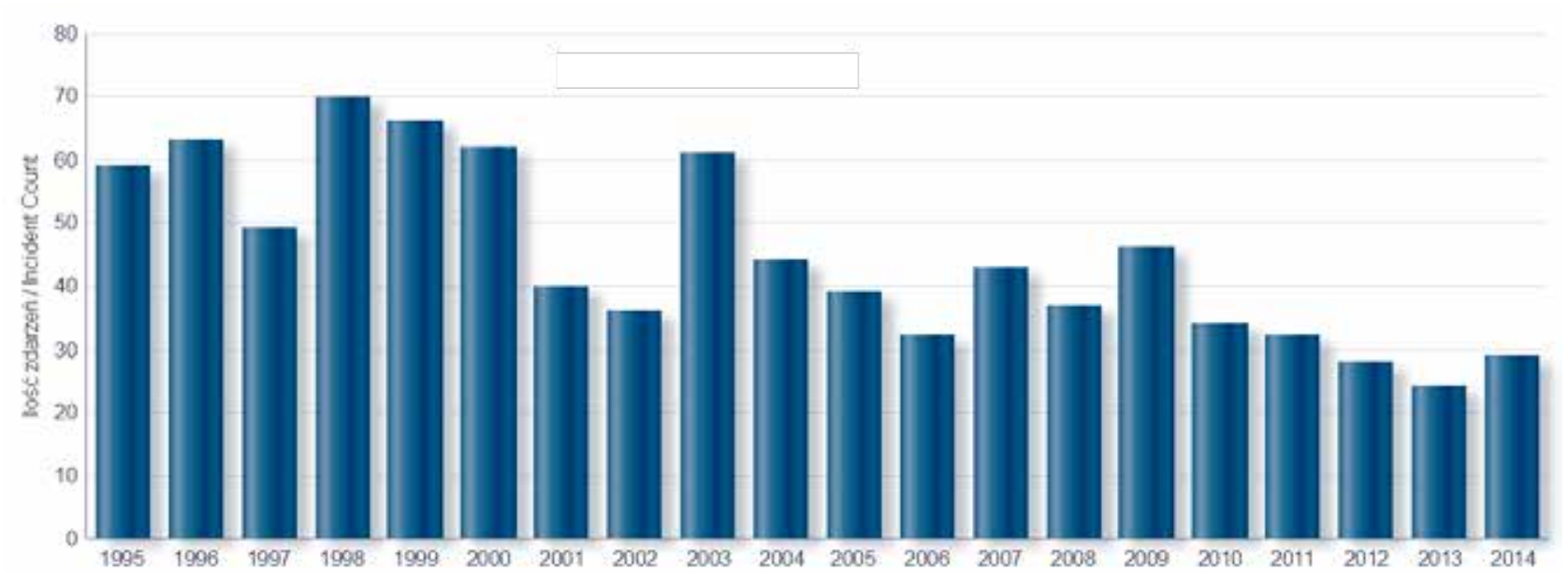

Ryc. 1. Znaczące awarie gazociągów w Stanach Zjednoczonych w latach 1994-2014 (na podstawie [1])

Fig. 1. Significant pipeline failures in the United States during the years 1994-2014 [1]

Łączna wartość zniszczeń i strat związanych z awariami wyniosła 1719312622 \$, co daje średnio rocznie 85965631 \$. W sumie w wyniku wypadków zginęło 41 osób, a 195 zostało rannych.

Do głównych przyczyn awarii gazociągów zalicza się korozję, zniszczenie podczas ekskawacji, nieprawidłową pracę gazociągu, awarie konstrukcyjne (np. wadliwe spoiny, wady materiałowe), szkody wywołane przez siły natury oraz inne czynniki zewnętrzne np. pożary w okolicy gazociągów, wypadki samochodowe. Procentowy udział poszczególnych przyczyn awarii gazociągów przedstawiono na wykresie na ryc. 2.
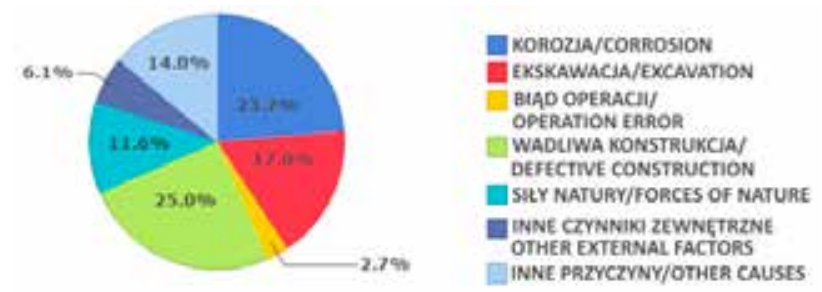

Ryc. 2. Przyczyny awarii gazociągów w Stanach Zjednoczonych w ciągu ostatnich 20 lat (na podstawie [1])

Fig. 2. Cause of pipeline failure in the United States over the past 20 years [1]

Gazociągi są niewątpliwie niezbędne do funkcjonowania współczesnego świata, jednak ryzyko ich awarii jest obciążone sporym faktorem zagrożenia. Studia przypadku sytuacji awaryjnych, które potencjalnie mogą powstać, oraz zdarzenia, które miały miejsce w przeszłości, przyczyniają się do powstania nowych rozwiązań zarówno w zakresie zabezpieczeń technicznych, jak i organizacyjnych.

\section{Awaria gazociągu $\mathrm{z}$ propanem w Port Hudson}

W związku z awarią rurociągu w Port Hudson w USA Narodowa Rada Bezpieczeństwa Transportu zleciła tamtejszemu Urzędowi Górnictwa przeprowadzenie śledztwa i sporządzenie raportu dotyczącego wybuchu gazu. Raport ten podsumowuje wypadek, który miał miejsce 9 grudnia 1970 roku, oraz jest próbą określenia charakteru eksplozji na podstawie wniosków wynikających ze zdarzenia. W raporcie skoncentrowano się przede wszystkim na identyfikacji możliwych źródeł zapłonu, obszarze rozprzestrzenienia propanu oraz analizie rozmiaru zniszczeń fali uderzeniowej.

\section{Opis wypadku}

Pierwszy sygnał o nieprawidłowym działaniu rurociągu odnotowany został o godzinie 22:07 przez pracownika stacji pomp znajdującej się w miejscowości Villa Ridge, oddalonej około $32 \mathrm{~km}$ na wschód od miejsca zdarzenia. Pompy zostały automatycznie zamknięte po 3 minutach, a spadek ciśnienia został rozprowadzony równomiernie w gazociągu. Dziesięć minut później gwałtownie wzrosła przepustowość w następnej stacji pomp położonej za miejscem zdarzenia w kierunku zgodnym z przepływem gazu. Był to jednoznaczny sygnał, że gdzieś nastąpiło przerwanie rurociągu. Ciśnienie wydobywającego się gazu w momencie rozerwania się rurociągu wynosiło około 65 bar. O godzinie 22:25 kilku świadków usłyszało dźwięk towarzyszący wypływającemu gazowi znajdującemu się pod wysokim ciśnieniem. Wysokość strumienia gazu wynosiła w pierwszej fazie od 15 do $25 \mathrm{~m}$ nad powierzchnią ziemi, a strumień gazu wypłukał w glebie zagłębienie o głębokości $1,2 \mathrm{~m}$ i średnicy $3 \mathrm{~m}$.

Na ryc. 3 zobrazowano mapę terenu, na którym doszło do zdarzenia. 


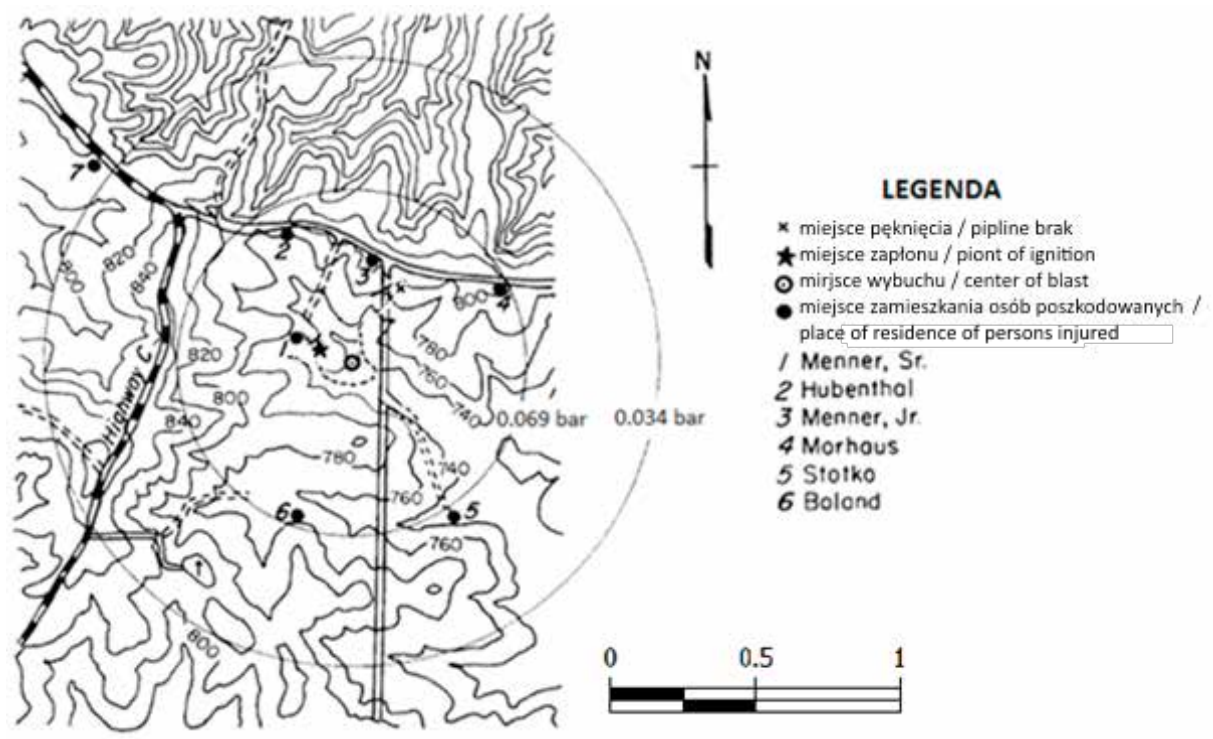

Ryc. 3. Rysunek na podstawie mapy opracowanej przez Amerykański Urząd Górnictwa (na podstawie [2])

Fig. 3. Diagram based on maps prepared by the Bureau of Mines [2]

W dalszym toku wypadków o godzinie 22:44 część mieszkańców okolic zdarzenia ewakuowała się ze swoich domów i zatrzymała się na skrzyżowaniu przy autostradzie „C”. Miejsce to położone jest na wzniesieniu, dlatego też świadkowie obserwowali stamtąd dalszy przebieg wydarzeń. Najpierw zauważono rozprzestrzeniającą się chmurę gazu, która wypełniała pobliską dolinę. Chmura objęła swym zasięgiem budynki znajdujące się w okolicy punktu nr $1 \mathrm{w}$ odległości około $300 \mathrm{~m}$ i 9-12 m poniżej źródła wycieku propanu. W dalszej części artykułu na ryc. 8 przedstawiono w przybliżeniu wymiary chmury gazu i rozpatrzono dwa rodzaje kształtu chmury. Domy w okolicach pkt 1 . na ryc. 3 zarówno w pierwszym, jak i w drugim przypadku, znalazły się w zasięgu mieszaniny wybuchowej.

Według świadków wybuch nastąpił około godziny 22:44. Wszyscy przyznali, że nie wystąpiło zjawisko rozchodzenia się płomienia w mieszaninie, ale że był to nagły rozbłysk światła oraz nastąpił efekt fali nadciśnienia. Jeden ze świadków znajdujący się w odległości $800 \mathrm{~m}$ od centrum wybuchu został powalony na ziemię wskutek przejścia fali nadciśnienia. Policjant, który znajdował się w samochodzie około $24 \mathrm{~km}$ od miejsca zdarzenia, odczuł wstrząsy. Sejsmograf na Uniwersytecie St. Louis, znajdującym się około $96 \mathrm{~km}$ na wschód, zanotował $2,2 \times 10^{-3} \mathrm{~mm}$ (poziomo) przesunięcia ziemi i podmuch powietrza o niemożliwej do określenia skali. Te zapisy pozwoliły oszacować czas wybuchu na 16 sekund po godzinie 22:44.

Zniszczenia budynków w sąsiedztwie wybuchu przedstawione są na ryc. 4-7. Ocena zniszczeń pozwala stwierdzić, że zjawiskiem zaobserwowanym przez świadków był silny wybuch gazu, który wygenerował falę ciśnienia.

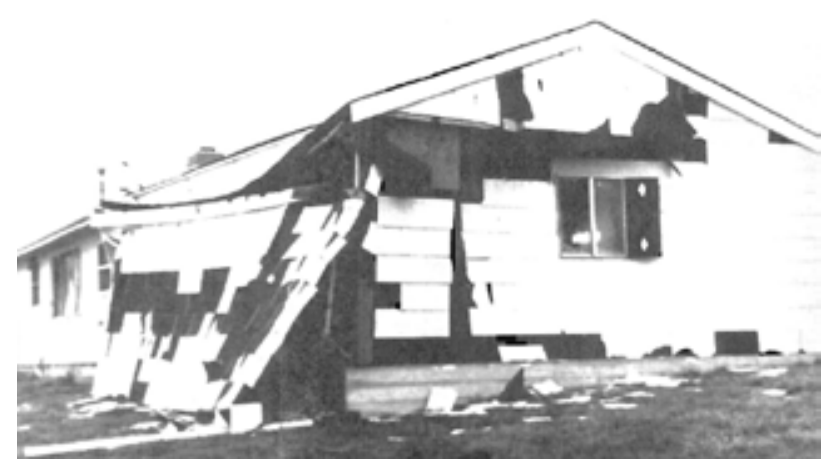

Ryc. 4. Zniszczenia domu rodziny Hubenthal około $500 \mathrm{~m} \mathrm{od}$ centrum wybuchu, pkt. 2 mapie (ryc. 3), (na podstawie [2])

Fig. 4. The destruction of the Hubenthal family house about $500 \mathrm{~m}$ from the centre of the explosion, item 2 on the map (fig. 3) [2]

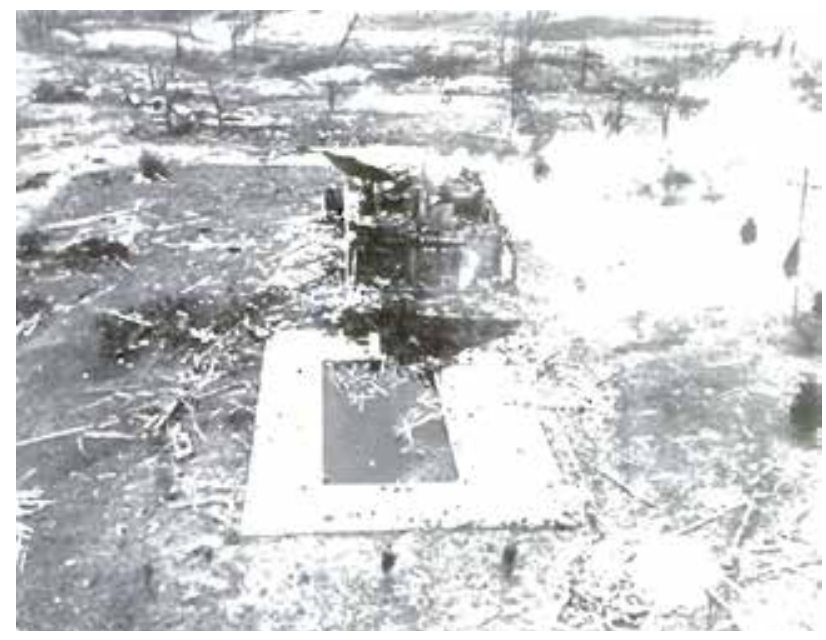

Ryc. 5. Pozostałości po budynku nr 1, położonym najbliżej epicentrum wybuchu (na podstawie [2])

Fig. 5. The remains of building No. 1, closest to the epicentre of the explosion [2] 


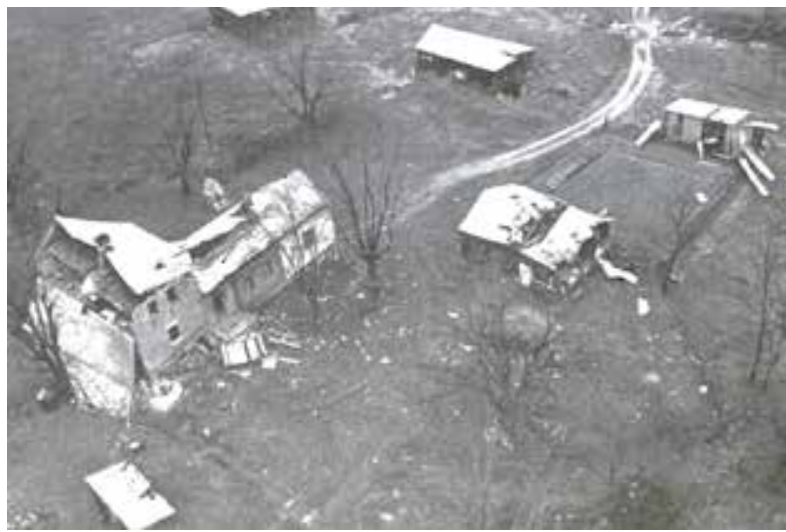

Ryc. 6. Zniszczenia budynku nr 5 położonego $610 \mathrm{~m} \mathrm{od}$ epicentrum wybuchu (na podstawie [2])

Fig. 6. Destruction of building No. 5 located 610 meters from the epicentre of the explosion [2]
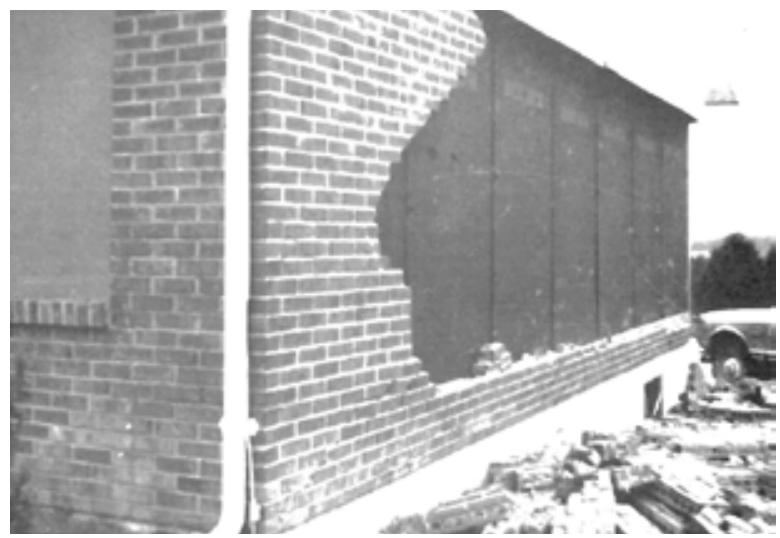

Ryc. 7. Zniszczenia ściany budynku nr 4, położonego około $600 \mathrm{~m}$ od epicentrum wybuchu, (na podstawie [2])

Fig. 7. Destruction of walls, of building No. 4, located about 600 meters from the epicentre of the explosion [2]

W kolejnych sekundach po wybuchu obserwowano rozchodzący się płomień, który spalał pozostałości mieszaniny propan-powietrze w kierunku zachodnim, w stronę autostrady „C”. Większość obserwatorów zdarzenia niezwłocznie przejechało w kierunku północno-zachodnim. Po przybyciu na farmę oznaczoną nr 7 na ryc. 3, około $1,2 \mathrm{~km}$ od strony wydarzenia zaobserwowano szczątki budynków gospodarczych Mennera (oznaczonych na ryc. 3 jako nr 1).

W prowadzonych później pracach nad wyjaśnieniem przebiegu wydarzeń oszacowano, że w ciągu pierwszych 24 minut od rozerwania rurociągu wypłynęło $120 \mathrm{~m}^{3}$ ciekłego propanu.

\section{Możliwe źródła zapłonu}

Rozważania na temat potencjalnych źródeł zapłonu rozpoczęto od najbardziej prawdopodobnej możliwości, czyli zapłonu w miejscu wycieku. W tym przypadku propan mógł zapalić się od elektryczności statycznej, poprzez wstrząsy spowodowane wysokim ciśnieniem rozpryskującego się propanu lub przez tarcie rozgrzanych cząstek, takich jak rdza oderwana od rurociągu. Jednakże po 24 minutach wypływu propanu wyrwa otaczająca uszkodzoną rurę musiała być niemalże całkowicie wypełniona czystym propanem, zatem prawdopodobnie stężenie byłoby kilkakrotnie większe niż górna granica wybuchowości propanu, co oznacza, że takie źródło zapłonu byłoby nieskuteczne. Niewykluczone, że elektryczność statyczna mogła zaistnieć wysoko w chmurze gazu. Jednak taki sposób zapłonu zostałby zauważony przez świadków.

Drugim potencjalnym źródłem zapłonu było otoczenie domu Mennera (ryc. 5). Budynek ten znajdował się nieznacznie wyżej niż pozostałe zabudowania gospodarcze i na podstawie dowodów wiadomo, że był poza zasięgiem łatwopalnej strefy chmury propanu. Zauważono, że trawa oraz rośliny wokół domu były prawie niespalone (brak pożaru przestrzennego).

Około $45 \mathrm{~m}$ na południowy wschód od domu Mennera stał murowany magazyn i to najprawdopodobniej w tym miejscu nastąpiło zainicjowanie zapłonu. Na parterze budynku znajdowały się cztery pomieszczenia, zawierające sześć zamrażarek, które pracowały w chwili zdarzenia. Ze względu na nieszczelności w przesuwanych drzwiach garażowych część gazu mogła przedostać się do wnętrza budynku i wytworzyć w środku mieszankę wybuchową. Zakłada się, że zapłon mieszanki mógł pojawić się w panelu kontrolnym chłodziarki. Gdy płomienie wypełniły wnętrze magazynu, turbulencje powstałe przy drzwiach znacznie przyspieszyły proces spalania i w całym budynku mogła skumulować się ogromna ilość energii. Powstałe ciśnienie wygenerowane w stałej objętości (wnętrze budynku) zostało skierowane na zewnątrz przez otwory budynku (okna, drzwi), wyzwalając energię wystarczającą do zapoczątkowania detonacji.

\section{Tworzenie się mieszaniny wybuchowej}

Na ryc. 8 przedstawione zostały rozmiary i przypuszczalny zasięg strefy wybuchowej obliczone przez autorów raportu. Zaprezentowano dwa modele obliczeń oznaczone jako A i B. W obu przypadkach założono jednostajny wyciek gazu, a obliczony przepływ propanu wyniósł $25,5 \mathrm{~m}^{3} / \mathrm{s}$. Za średnią prędkość wiatru przyjęto $3 \mathrm{~m} / \mathrm{s}$.
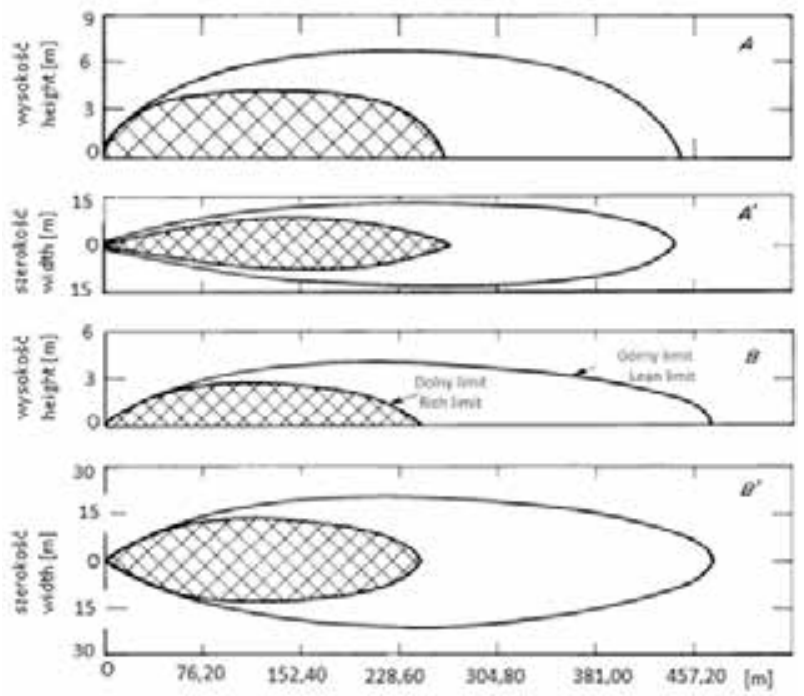

Ryc. 8. Przypuszczalne rozmiary chmury propanu, widok $z$ boku i z góry - (A, A') metodą A i (B, B') metodą $B$, (na podstawie [2])

Fig. 8. Putative propane cloud dimensions, side and top views (A, A') by method A, and (B, B') by method B (based on [2]) 
Uzyskane maksymalne stężenia wahały się od 35\% propanu na odległości $91 \mathrm{~m}$ do 2,8\% propanu na odległości $448 \mathrm{~m}$ od źródła. Granice wybuchowości 7,0\% (GGW) i $2,8 \%$ (DGW) propanu zostały podane na ryc. 8 (B, B'). Długość chmury wybuchowej jest wydłużona w stosunku do A z 448,06 m do 472,44 m i obszar zwiększony jest $\mathrm{z} 9712,5 \mathrm{~m}^{2}$ do $15378,1 \mathrm{~m}^{2}$. Jakkolwiek $\mathrm{z}$ powodu zmniejszenia maksymalnej wysokości chmury z $6,71 \mathrm{~m}$ do 4,27 m wielkość chmury detonacyjnej zwiększyła się jedynie z $31100 \mathrm{~m}^{3}$ do $42500 \mathrm{~m}^{3}$.

Objętość propanu w mieszaninie $\mathrm{z}$ powietrzem oszacowano w raporcie na około $1529,1 \mathrm{~m}^{3}$. Przy uwzględnieniu gęstości propanu w warunkach standardowych $\left(1,882 \mathrm{~kg} / \mathrm{m}^{3}\right)$ jego masa wynosiłaby $2877,8 \mathrm{~kg}$.

W powyższych kalkulacjach nie ujęto cięższej od powietrza mieszaniny gazowej zalegającej przy powierzchni terenu, która powstała $\mathrm{z}$ uwagi na bardzo stabilne warunki pogodowe. Tabela nr 1 zawiera listę warunków meteorologicznych w miejscu i czasie zdarzenia oszacowane przez National Weather Service. Niska prędkość wiatru przy powierzchni, małe zachmurzenie, inwersja temperatury na poziomie $600 \mathrm{~m}$ sugerują stabilność atmosfery w kategorii F.

Tabela 1. Warunki pogodowe w czasie zdarzenia zarejestrowane przez stację meteorologiczną w Port Hudson (na podstawie [2])

Table 1. Weather conditions during the incident, recorded by the meteorological station at Port Hudson (based on [2])

\begin{tabular}{|c|c|c|c|}
\hline $\begin{array}{c}\text { Wysokość/ } \\
\text { Height }[\mathbf{m}]\end{array}$ & $\begin{array}{c}\text { Temperatura/ } \\
\text { Temperature } \\
{\left[{ }^{\circ} \mathbf{C}\right]}\end{array}$ & $\begin{array}{c}\text { Prędkość } \\
\text { wiatru/ Wind } \\
\text { velocity } \\
{[\mathbf{m} / \mathbf{s}]}\end{array}$ & $\begin{array}{c}\text { Kierunek } \\
\text { wiatru } \\
\text { / Wind } \\
\text { direction }\end{array}$ \\
\hline 0 & 1 & 2,5 & $60^{\circ}$ \\
\hline 150 & 3 & 4,1 & $70^{\circ}$ \\
\hline 300 & 7 & 5,2 & $90^{\circ}$ \\
\hline 600 & 11 & 5,2 & $90^{\circ}$ \\
\hline 900 & 9 & 5,2 & $193^{\circ}$ \\
\hline 1500 & 6 & 6,2 & $228^{\circ}$ \\
\hline
\end{tabular}

Nachylenie terenu, na którym miało miejsce przedstawione zdarzenie, wynosi około $2 \%$. Stąd też należałoby oczekiwać, że warstwa propanu spłynie do niższych poziomów doliny.

Bardzo istotne dla charakteru dyspersji propanu miały warunki początkowe wycieku. Skoro propan został uwolniony do atmosfery jako ciecz pod wysokim ciśnieniem o temperaturze $1^{\circ} \mathrm{C}$, to około $1 / 4 \mathrm{z}$ tego musiała być natychmiast odparowana, chłodząc jego pozostałą część i doprowadzając do punktu wrzenia wynoszącego $-42^{\circ} \mathrm{C}$. W tych warunkach gęstość propanu w fazie gazowej wynosi 2,417 $\mathrm{kg} / \mathrm{m}^{3}$. Według świadków propan w postaci skroplonej został rozproszony jako słup o wysokości od 15 do $24 \mathrm{~m}$. Istotny jest fakt, że kropelki propanu pobierają ciepło do parowania raczej z otaczającego powietrza niż z ziemi. Daje to zapotrzebowanie ciepła zawartego w około 4,08 $\mathrm{kg}$ powietrza o temperaturze $1^{\circ} \mathrm{C}$ do przeprowadzenia w fazę gazową $0,45 \mathrm{~kg}$ propanu o temperaturze $-42^{\circ} \mathrm{C}$. Otrzymana mieszanka, która wynosi $10 \%$ wagowych lub
$7 \%$ objętościowych propanu o temp. $-42{ }^{\circ} \mathrm{C}$, jest o $20 \%$ gęstsza niż otaczające ją powietrze.

\section{Analiza zniszczeń}

Podczas oględzin zniszczenia podzielono na dwie strefy. Na podstawie tych danych można odnieść się do masy TNT, która spowodowałaby zniszczenia równe tym, które powstały w wyniku eksplozji propanu.

1. Zniszczenia struktury domów i okolicznych zabudowań, gdzie nadciśnienie wynosiło około $6,9 \mathrm{kPa}$ lub więcej.

2. Straty w odległym terenie, gdzie nadciśnienie mogło wynosić około $0,24 \mathrm{kPa}$.

Liczba zniszczonych posesji została podana w tabeli 2. Dane te zostały użyte do wygenerowania skumulowanych wartości procentowych zniszczeń. Zniszczenia zaobserwowano w promieniu $8047 \mathrm{~m}$, najwięcej zniszczeń $(97,3 \%)$ znalazło się w promieniu $1609 \mathrm{~m} \mathrm{od}$ epicentrum wybuchu.

Tabela 2. Liczba zniszczonych obiektów (na podstawie [2]) Table 2. The number of destroyed buildings [2]

\begin{tabular}{|c|c|c|}
\hline $\begin{array}{c}\text { Odległość/ } \\
\text { Distance [m] }\end{array}$ & $\begin{array}{c}\text { Zniszczone obiekty } \\
\text { liczba/ } \\
\text { The number } \\
\text { of destroyed } \\
\text { buildings }\end{array}$ & $\begin{array}{c}\text { Zniszczenia/ } \\
\text { Destruction [\%] }\end{array}$ \\
\hline 1609 & 36 & 97,3 \\
\hline 3219 & 69 & 75 \\
\hline 4828 & 97 & 57,7 \\
\hline 6437 & 109 & 38,4 \\
\hline 8047 & 126 & 30 \\
\hline
\end{tabular}

- Zniszczenia w odległości $800 \mathrm{~m}$ od wybuchu.

Ryciny 4-7 pokazują następstwa wybuchu dla kilku obiektów znajdujących się w zasięgu obłoku propanu. Prawdopodobne centrum wybuchu zostało oznaczone na mapie na ryc. 3. Można założyć, że 3 z 5 budynków zostało zniszczonych siłą wybuchu odpowiadającej detonacji 45-68 ton TNT. Posesja Stotko (pozycja 6 na ryc. 3) została uszkodzona w takim stopniu, że żadne racjonalne umieszczenie centrum wybuchu nie mogło spowodować zniszczeń równych takiej sile, w porównaniu do skali zniszczeń pozostałych budynków. Przypuszcza się, że topografia terenu spowodowała skupienie impulsu ciśnienia na tym budynku. Ostatecznie można oczekiwać, że zniszczenia mogły być większe w bliższym obszarze w kierunku rozprzestrzeniania się detonacji. Pomimo tych ograniczeń twierdzenie, że domostwa w sąsiedztwie zostały zniszczone przez siłę równą detonacji 45-68 ton TNT umieszczonego w centrum wybuchu, pozostaje prawdziwe.

- Niewielkie zniszczenia w dalekiej odległości.

Przez wiele lat korzystano ze stopnia zniszczenia okien po wybuchu jako wyznacznika uwolnionej energii. Starsze opracowania podają krytyczne ciśnienie równe 3,4-6,9 $\mathrm{kPa}$ dla stłuczenia szyb. Odnosząc te wartości do opisywanego zdarzenia, można by wywnioskować, że takie zniszczenie powinno być ograniczone do małego terenu 
wokół wybuchu. Jednakże w sytuacji, gdy w nowoczesnych budowlach powierzchnia okien jest większa, wartość krytycznego ciśnienia wymaganego do rozbicia szyb jest mniejsza. Obecnie akceptuje się ciśnienie rzędu 3,4 kPa jako wystarczające [3].

\section{Analiza zdarzenia w RizEx}

Program RizEx-2 został zaprojektowany, aby wspomagać procedury oceny ryzyka w obiektach, dla których istnieje duże prawdopodobieństwo wystąpienia awarii. W tym rozdziale przeanalizowana zostanie możliwość wykorzystania programu do odtworzenia wypadków z udziałem substancji niebezpiecznych w terenie innym niż przemysłowy.

Moduły numeryczne pakietu oprogramowania RizEx-2 służą do obrazowania procesów fizycznych, w przypadku wystąpienia zdarzenia awaryjnego, takich jak np. dyspersja gazów, parowanie cieczy, pożar czy wybuch. Każdy moduł obliczeniowy wykonuje także symulacje rozwoju tych procesów na podstawie modeli numerycznych odpowiadających charakterowi procesów i uwzględniających towarzyszące im warunki (np. warunki meteorologiczne, pokrycie terenu).

Poniżej zawarto listę modułów oferowanych przez pakiet RizEx-2 oraz krótki opis ich funkcji [5-7].

- Data Base (Baza właściwości substancji niebezpiecznych) - zawiera minimalny zestaw danych, potrzebnych do obliczeń przez poszczególne moduły. Bazę można edytować za pomocą programu Microsoft Access.

- Fault Tree (Drzewo błędów) - symulacja zdarzenia przy pomocy drzewa błędów, obliczanie prawdopodobieństwa zdarzenia w drzewie błędów, analiza minimalnego prawdopodobieństwa wypadku.

- Reliability Data Base (Baza danych niezawodnościowych) - zawiera bazę danych określającą prawdopodobieństwo awarii różnych typów urządzeń technologicznych.

- Accidents (Zdarzenia awaryjne) - moduł pozwala na uzyskanie ilościowej analizy prawdopodobieństwa zaistnienia zagrożeń fizycznych w wyniku awarii aparatury.

- Event Tree (Drzewo zdarzeń) - symulacja rozwoju warunków wypadku z użyciem drzewa zdarzeń, obliczanie prawdopodobieństwa zaistnienia awaryjnych zdarzeń, analiza efektywności i niezawodności środków ochronnych. Poszukiwanie rozwiązań w celu zwiększenia wydajności i niezawodności środków ochronnych.

- Liquid Discharge (Wypływ cieczy) - symulacja dynamiki wypływu fazy ciekłej ze zbiorników o różnych kształtach, uwzględniająca lokalne i hydrauliczne opory oraz określenie warunków powstania rozlewiska dla palnych, niebezpiecznych i toksycznych substancji.

- Gas Release (Uwolnienie gazu) - symulacja dynamiki wypływu gazu ze zbiorników o różnych kształtach, uwzględniająca lokalne i hydrauliczne opory oraz określenie warunków formowania mieszaniny gaz/ powietrze.

- Evaporation (Odparowanie) - obliczenie przepływu fazy gazowej do atmosfery w przypadku uwolnienia podgrzanej mieszaniny wieloskładnikowej oraz odparowania z powierzchni rozlewiska.
- Dispersion Gaussian Model Neutral Gas (Dyspersja, Model Gaussa Gaz neutralny) - wyznaczenie zmiany stężenia substancji gazowych w czasie od momentu uwolnienia $\mathrm{w}$ każdym punkcie przestrzeni, $\mathrm{z}$ uwzględnieniem warunków atmosferycznych, kierunku oraz siły wiatru. Graniczna wartość toksycznej dawki substancji. Określenie szybkości ewakuacji i prawdopodobieństwa obrażeń osób jako rezultatu zatrucia. Zastosowanie modelu Gaussa.

- Formation of Explosion-Hazardous Cloud (Formowanie atmosfery wybuchowej) - określenie zmiany masy substancji, pomiędzy górną a dolną granicą palności, w czasie.

- Explosion: Calculation Based on Empirical Relationships (Wybuch: Obliczenie oparte na zależnościach empirycznych) - symulacja propagacji fali ciśnienia $\mathrm{w}$ mieszaninie palnej w przypadku wybuchu substancji $\mathrm{w}$ fazie skondensowanej. Zdefiniowanie wpływu fali ciśnienia na obiekty. Obszar zniszczeń oraz stopień zniszczenia budynków. Określenie stref rażenia o różnych stopniach nasilenia, uwzględniając przypadki śmiertelne, jak również prawdopodobieństwo narażenia zdrowia znajdujących się w tych strefach.

- Fire, Calculation by Empirical Relationships (Pożar, Obliczenia oparte na zależnościach empirycznych) określenie prawdopodobieństwa oddziaływania promieniowania cieplnego na ludzi, jak również możliwości zapłonu materiałów narażonych na działanie strumienia ciepła.

- Fire, 3D Model (Pożar Model 3D) - natężenie przepływu cieplnego od płomieni do narażonych powierzchni, przedstawione w przestrzeni trójwymiarowej, określone poprzez całkowanie równań opisujących przepływy cieplne. Prawdopodobieństwo wypadków z udziałem ludzi na drogach ewakuacyjnych. Prawdopodobieństwo zapłonu materiałów znajdujących się w obiektach poddanych obciążeniom cieplnym,

- Torch (Pożar strumieniowy) - takie same charakterystyki jak w punkcie 13 są określane dla pożaru strumieniowego typu poziomego lub pionowego.

- Risk (Ryzyko) - wyznaczenie obszarów lokalnego ryzyka w badanym obiekcie przemysłowym opisanego i zdefiniowanego przez ekspertów. Pojedyncze ryzyko określane jest dla konkretnych obszarów (zakładu przemysłowego, obszaru wiejskiego, dzielnicy miasta itp.). Przypuszczalna liczba ofiar (ryzyko społeczne) określana jest $\mathrm{z}$ uwzględnieniem gęstości zaludnienia $\mathrm{w}$ analizowanym regionie.

Fragment Dispersion (Odłamkowanie) - symulacja trajektorii lotu odłamków z uwzględnieniem warunków zniszczenia zbiornika, kąta trajektorii lotu oraz masy i kształtu fragmentów. Określenie prędkości przemieszczania się fragmentów w każdym punkcie trajektorii, z uwzględnieniem oporów powietrza i panujących warunków. Prawdopodobieństwo zderzenia z obiektami. Do wykonania symulacji zdarzenia w Port Hudson skorzystano z modułów:

- Dispersion Gaussian Model - Neutral Gas - dyspersja substancji niebezpiecznej z użyciem modelu Gaussa.

- Formation of Explosion-Hazardous Cloud - formowanie strefy wybuchowej. 
- Explosion - oszacowanie nadciśnienia powstałego w wyniku eksplozji oraz obszaru objętego jego skutkami. Aby uzyskać lepszy obraz tego, jak program poradzi sobie z odzwierciedleniem zdarzenia w Port Hudson, założono wystąpienie takich samych warunków pogodowych oraz prędkości wycieku propanu, które zostały podane $\mathrm{w}$ raporcie. Rozpatrzono dwa scenariusze rozwoju wydarzeń. W scenariuszu 1 przyjęto prędkość wiatru równą $3 \mathrm{~m} / \mathrm{s}$, a w scenariuszu 2 równą $4 \mathrm{~m} / \mathrm{s}$.

\subsection{Formowanie strefy wybuchowej}

Do symulacji dyspersji propanu w powietrzu zastosowano dwa moduły programu RizEx-2 - Formation of Explosion-Hazardous Cloud oraz Dispersion Gaussian Model - Neutral Gas.

Każdy z ww. modułów umożliwia wybór jednego z trzech scenariuszy:

- natychmiastowy wyciek zawartości gazu z uszkodzonej aparatury,

- ciągły wyciek gazu z uszkodzonej aparatury,

- parowanie substancji po wycieku.

Wynikiem symulacji w omawianych modułach jest wartość stężenia substancji gazowej w określonej odległości od miejsca wycieku, jak również jej zasięg i wysokość nad ziemią. Innymi słowy powstaje rozkład stężenia w przestrzeni trójwymiarowej. Modele oparte są na technice polegającej na określeniu zmian stężenia substancji niebezpiecznej w czasie i przestrzeni, z uwzględnieniem prędkości i kierunku wiatru. Obliczenia wykonane są na podstawie zależności z rozkładu Gaussa.

Możliwości obu modułów są podobne, jednak istnieją między nimi dwie istotne różnice. Pierwsza różnica polega na tym, że model Formation of Explosion-Hazardous Cloud przedstawia chmurę propanu o stężeniu wyższym niż dolna granica wybuchowości, natomiast Dispersion Gaussian
Model - Neutral Gas obrazuje cały zakres rozkładu stężenia tej chmury.

Kolejna różnica dotyczy dodatkowej funkcji pierwszego z omawianych modułów. Za pomocą Formation of Explosion-Hazardous Cloud możliwe jest wyznaczenie masy propanu zawartej pomiędzy dolną a górną granicą wybuchowości. Nie jest to możliwe w przypadku zastosowania modułu Dispersion Gaussian Model - Neutral Gas.

Na potrzeby wykonania symulacji zdarzenia awaryjnego w Port Hudson wybrano scenariusz zakładający ciągły, jednostajny wyciek gazu z prędkością o wartości identycznej, jak ta podana $\mathrm{w}$ raporcie równej $25,5 \mathrm{~m}^{3} / \mathrm{s}$. Po wybraniu modelu i scenariusza, do programu wprowadzono niezbędne dane. Następnie uruchomiona została sekwencja obliczeniowa, której rezultat w postaci rozkładu stężenia utworzonej chmury program przedstawił w formie graficznej na mapie (ryc. $9 \mathrm{i} 10$ ). Na ryc. 9 przedstawiono wynik obliczeń dla scenariusza 1 , a na ryc. 10 - dla scenariusza 2 . Na rycinach w punkcie „a” zobrazowano rozkład stężenia uzyskany w modelu Dispersion Gaussian Model - Neutral Gas, a w punkcie „b” w modelu Formation of Explosion-Hazardous Cloud. Program umożliwia „przecięcie” wygenerowanej chmury w dowolnym miejscu. W tym przypadku wykonano tę operację: „a” w poprzek i „b” wzdłuż powstałej chmury propanu. Miejsca te oznaczono na rycinach 9 i 10 za pomocą strzałek. Po wybraniu miejsca przekroju program automatycznie wygenerował wykresy przedstawiające rozkład stężeń na wybranym odcinku, zgodnie z wartościami wskazanymi na rycinach 9 i $10 . Z$ wygenerowanych wykresów wynika, że najwyższe stężenie propanu występuje w centralnej części chmury oraz przy źródle wycieku gazu, co $\mathrm{w}$ dużym stopniu jest zbieżne z tezą określoną w trakcie badań przez Urząd Górniczy Stanów Zjednoczonych (U.S. Bureau of Mines), o braku możliwości wystąpienia aktywnego źródła zapłonu w tym obszarze.

a) Dispersion Gaussian Model - Neutral Gas
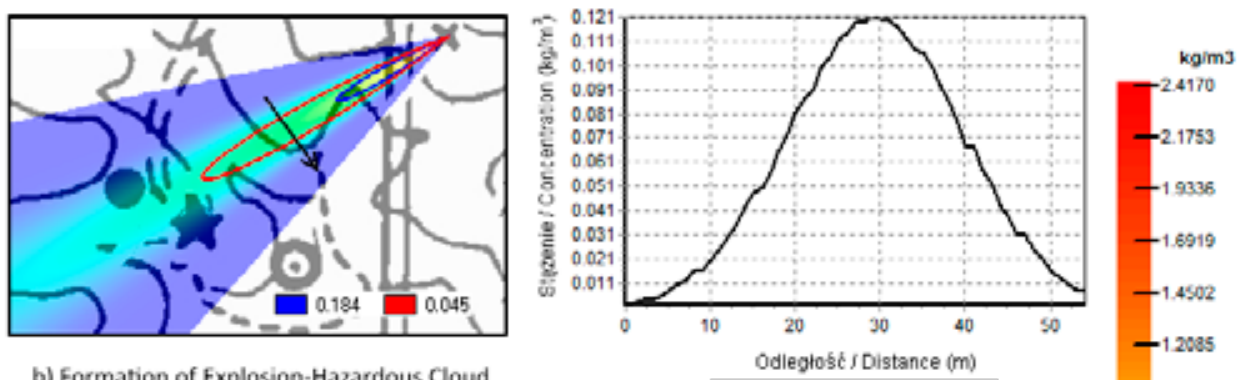

b) Formation of Explosion-Hazardous Cloud
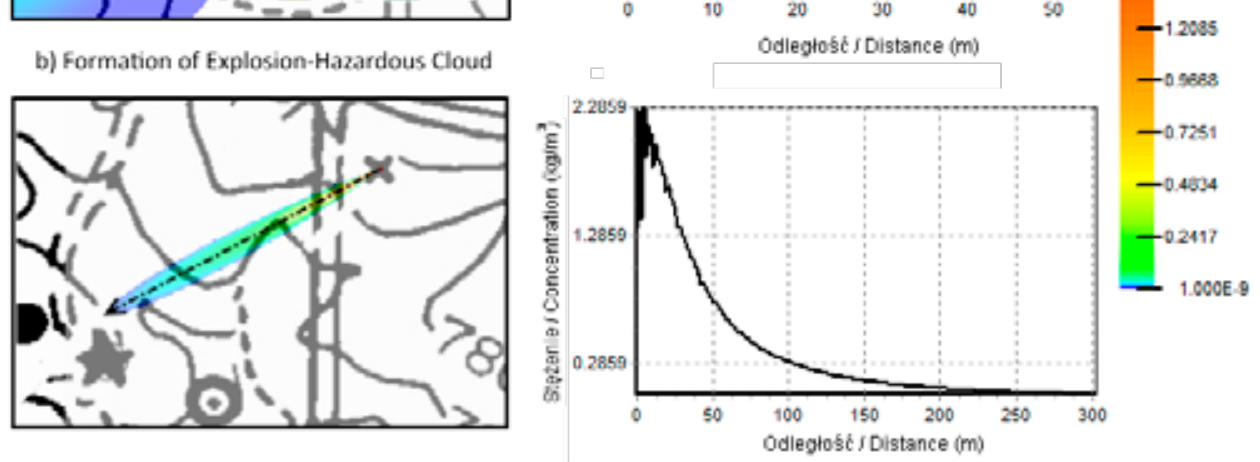

Ryc. 9. Dyspersja propanu w scenariuszu 1

Fig. 9. The dispersion of propane in scenario 1

Źródło: Opracowanie własne.

Source: Own elaboration. 
a) Dispersion Gaussian Model - Neutral Gas
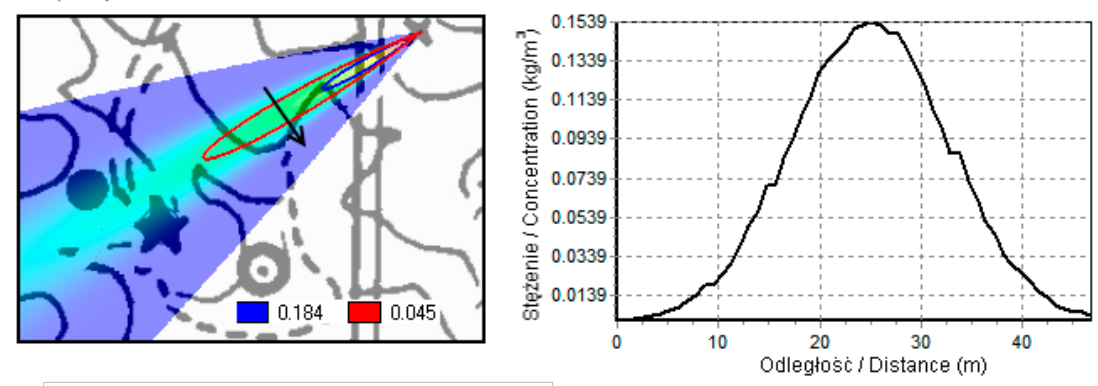

b) Formation of Explosion-Hazardous Cloud
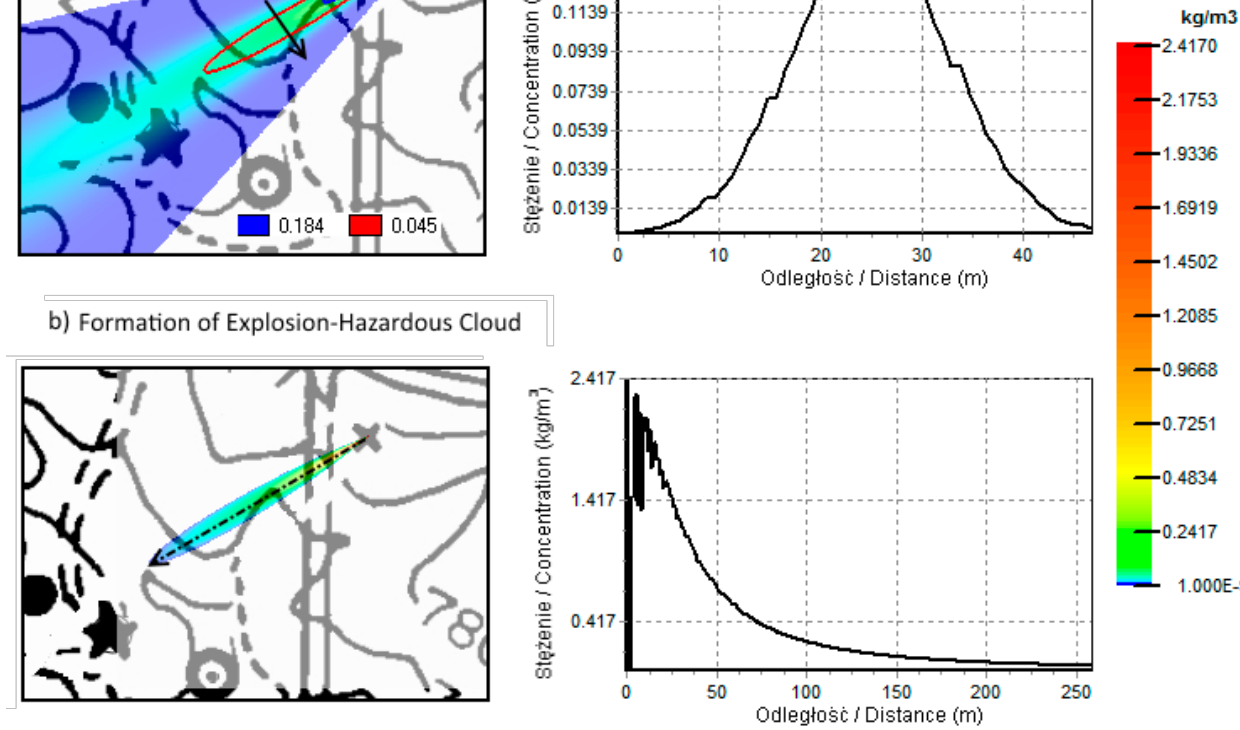

Ryc. 10. Dyspersja propanu w scenariuszu 2

Fig. 10. The dispersion of propane in scenario 2

Źródło: Opracowanie własne.

Source: Own elaboration.

Po prawej stronie na rycinach 9 i 10 znajduje się skala gradientowa. Program automatycznie przyporządkowuje różnym kolorom wartości stężenia. Kolor czerwony reprezentuje maksymalną wartość stężenia w powstałej chmurze propanu, której wartość podaje użytkownik w oparciu o warunki zaistniałego zdarzenia. W tym przypadku wyniosła ona $2,417 \mathrm{~kg} / \mathrm{m}^{3}$. Jest to wartość równa gęstości propanu w temperaturze jego wrzenia, wynoszącej $-42^{\circ} \mathrm{C}$. Jak już wcześniej wspomniano, gaz ulatniał się $\mathrm{z}$ rurociągu pracującego pod ciśnieniem, dlatego w wyniku rozprężenia ochłodził się on w miejscu wycieku do takiej temperatury.

Bardzo użyteczną opcją w zastosowanym module jest możliwość naniesienia na otrzymaną mapę granic obszaru wybuchowego. Na rycinach 9 oraz 10 dolną granicę wybuchowości oznaczono linią czerwoną, natomiast górną granicę wybuchowości - linią niebieską. Granice te wyrażone są w $\mathrm{kg} / \mathrm{m}^{3}$.

Zgodnie z raportem najbardziej prawdopodobnym miejscem inicjacji wybuchu był magazyn z chłodziarkami, oznaczony na rycinach 3, 9 i 10 symbolem gwiazdy. Jednak mieszanina propanu z powietrzem o stężeniu pomiędzy dolną a górną granicą wybuchowości wyznaczona w programie RizEx-2 nie objęła swoim zasięgiem ani miejsca wskazanego przez Urząd Górnictwa, ani innych budynków na mapie. Zatem na podstawie wniosków z obliczeń należałoby zaproponować inne źródło zapłonu oraz jego miejsce wystąpienia. Nawiązując do rozważań opisanych w raporcie opisanych w rozdziale 4 niniejszego artykułu, propan mógł zapalić się od elektryczności statycznej poprzez wstrząsy spowodowane wysokim ciśnieniem rozpryskującego się propanu lub przez tarcie rozgrzanych cząstek, takich jak rdza oderwana od rurociągu.
Następny etap stanowiło wyznaczenie masy propanu, który znajdował się w mieszaninie z powietrzem pomiędzy dolną a górną granicą wybuchowości oraz jego zasięgu. Wartość ta jest równa masie gazu, która wzięła udział w eksplozji. Na rycinach 11 i 12 znajdują się wykresy zależności masy propanu pomiędzy dolną a górną granicą wybuchowości od czasu, który upłynął od momentu przerwania rurociągu. Mimo że całkowity czas uwolnienia trwał 24 minuty (wartość tę uwzględnia program), RizEx-2 przedstawił wyniki tylko do momentu ustabilizowania się masy propanu. Dla scenariusza 1 masa propanu pomiędzy dolną a górną granicą wybuchowości ustabilizowała się po ok. 100 s, natomiast dla scenariusza 2 - po ok. 65 s. Wartość ta nie uległa zmianie przez cały czas wypływu gazu aż do momentu zainicjowania wybuchu w 24 minucie.

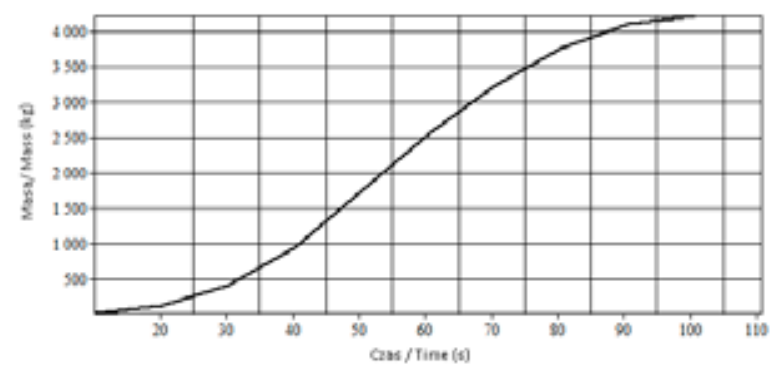

Ryc. 11. Zależność masy propanu w stężeniu pomiędzy dolną a górną granicą wybuchowości od czasu dla scenariusza 1

Fig. 11. The dependence of the mass of propane over time for scenario 1

Źródło: Opracowanie własne. Source: Own elaboration. 


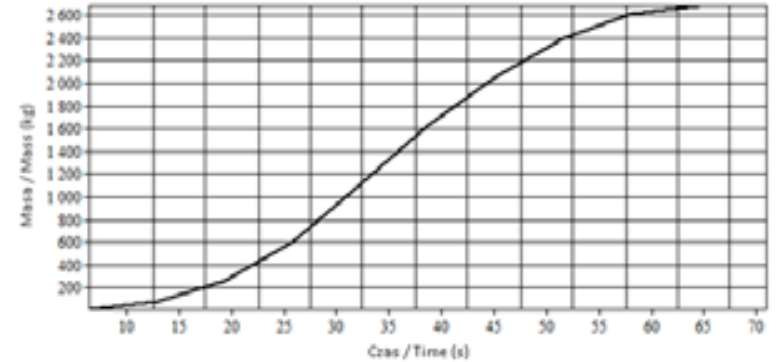

Ryc. 12. Zależność masy propanu w stężeniu pomiędzy dolną a górną granicą wybuchowości od czasu dla scenariusza 2

Fig. 12. The dependence of the mass of propane over time for scenario 2

Źródło: Opracowanie własne. Source: Own elaboration.

Na podstawie wyżej opisanych wykresów można stwierdzić, że wzrost prędkości wiatru o $1 \mathrm{~m} / \mathrm{s}$ zmniejsza masę propanu pomiędzy dolną, a górną granicą wybuchowości z $4205 \mathrm{~kg}$ przy wietrze o prędkości $3 \mathrm{~m} / \mathrm{s}$, na $2683 \mathrm{~kg}$ przy prędkości wiatru wynoszącej $4 \mathrm{~m} / \mathrm{s}$.

Program wyznaczył również zasięg oraz szerokość dolnej granicy wybuchowości propanu. Dla scenariusza 1 zasięg wyniósł $302 \mathrm{~m}$, a szerokość $33 \mathrm{~m}$. Z kolei dla scenariusza 2 - odpowiednio $256 \mathrm{~m}$ i $28 \mathrm{~m}$. Wartości te odczytane zostały $\mathrm{z}$ raportu wygenerowanego $\mathrm{w}$ wyniku sekwencji obliczeniowej. Wartość ta została wykorzystana do wykonania symulacji dalszych skutków wydarzenia $\mathrm{w}$ module Explosion.

\subsection{Analiza efektów eksplozji}

Model eksplozji zaproponowany przez RizEx oblicza zakres i siłę eksplozji na podstawie masy substancji biorącej udział w wybuchu. Otrzymane wartości zakresu eksplozji przedstawione zostały na ryc. $13 \mathrm{w}$ postaci stref $\mathrm{z}$ naniesionymi granicznymi wartościami nadciśnienia. Reprezentację tych wartości zestawiono $\mathrm{w}$ tabeli $3 \mathrm{w}$ postaci opisu zniszczeń.

Tabela 3. Efekt działania nadciśnienia na konstrukcje (na podstawie [4])

Table 3. The effect of overpressure on the construction [4]

\begin{tabular}{|c|c|}
\hline $\begin{array}{l}\text { Nadciśnienie/ } \\
\text { Overpressure }[\mathrm{kPa}]\end{array}$ & $\begin{array}{l}\text { Opis zniszczeń/ } \\
\text { Description of damage }\end{array}$ \\
\hline 3,4 & $\begin{array}{l}\text { Małe i duże szklane okna zbite, możliwe uszkodzenia ram okiennych / Small and large glass } \\
\text { window firm, possible damage to the window frames. }\end{array}$ \\
\hline 6,9 & $\begin{array}{l}\text { Częściowo uszkodzone domy, nie nadają się do dalszego zamieszkania / Partially damaged } \\
\text { houses, not suitable for further residence. }\end{array}$ \\
\hline 13,8 & $\begin{array}{l}\text { Częściowe zawalenie ścian i dachów domów / Partial collapse of walls and roofs of the } \\
\text { houses. }\end{array}$ \\
\hline 15,8 & $\begin{array}{l}\text { Dolny limit poważnych uszkodzeń konstrukcji budowlanych / The lower limit of serious } \\
\text { structural damage. }\end{array}$ \\
\hline 34,5 & Niemal całkowicie zniszczone domy / Almost completely destroyed houses. \\
\hline
\end{tabular}

Wyniki modelu wybuchu obliczonego dla scenariusza 1 są bardziej zgodne z wynikami raportu i lepiej odzwierciedlają efekty zdarzenia. Widać to na podstawie otrzymanych zakresów stref dla poszczególnych wartości nadciśnienia. Przykładowo według scenariusza 1 dom oznaczony $\mathrm{nr} 1$ znajdowałby się w strefie nadciśnienia do $15,8 \mathrm{kPa}$, co oznaczałoby na podstawie tabeli 3 poważne uszkodzenie jego konstrukcji. Znajduje to potwierdzenie w zebranej w raporcie dokumentacji (zob. zdjęcie domu nr 1 na ryc 5). Natomiast według scenariusza 2 dom ten znajdowałby się poza tym obszarem, co oznaczałoby mniejsze zniszczenia. Podobne wnioski można wysnuć na podstawie stanu domu nr 2. Zgodnie z założeniami scenariusza 1 dom ten znajdowałby się w strefie nadciśnienia do $6,9 \mathrm{kPa}$, a w scenariuszu 2 - poza tym obszarem. Na podstawie zdjęcia tego budynku (zob. ryc. 4), na którym widać wyraźnie uszkodzoną konstrukcję ścian, można stwierdzić, że nie nadawałby się on do dalszego zamieszkania. W związku z tym można jeszcze raz potwierdzić słuszność założeń scenariusza 1. 

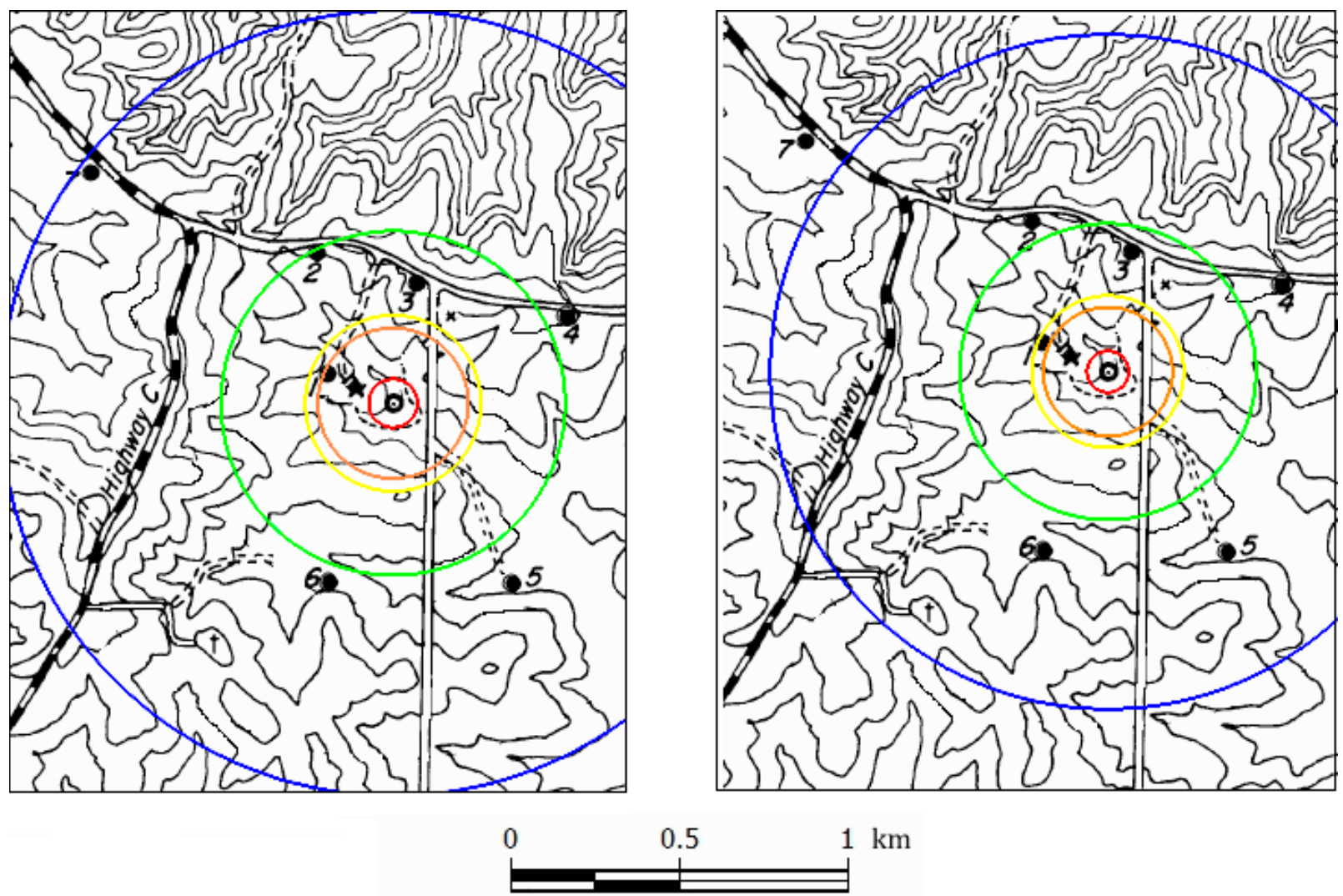

$\square 34.5 \quad \square 15.8 \quad \square 13.8 \quad \square 6.9 \quad \square 3.4 \quad[\mathrm{kPa}]$

Ryc. 13. Strefy działania ciśnienia wybuchu z podziałem na wartości krytyczne dla od lewej: scenariusza 1 i scenariusza 2 Fig. 13. Explosion of the pressure zone divided into critical values. From the left: Scenario 1 and Scenario 2

Źródło: Opracowanie własne.

Source: Own elaboration.

Program RizEx-2 umożliwia również oszacowanie promienia oddziaływania nadciśnienia wygenerowanego przez eksplozję. Na ryc. 14 znajdują się wykresy przedstawiające te wartości w zależności od odległości od miejsca wybuchu dla scenariusza 1 oraz scenariusza 2. Minimalna wartość nadciśnienia rejestrowana przez program wynosi $1 \mathrm{kPa}$, poniżej tej wartości program nie generuje wyników. Zasiąg działania minimalnego nadciśnienia w przypadku pierwszym wynosi około $3500 \mathrm{~m}$, natomiast w drugim przypadku - około $3000 \mathrm{~m}$.

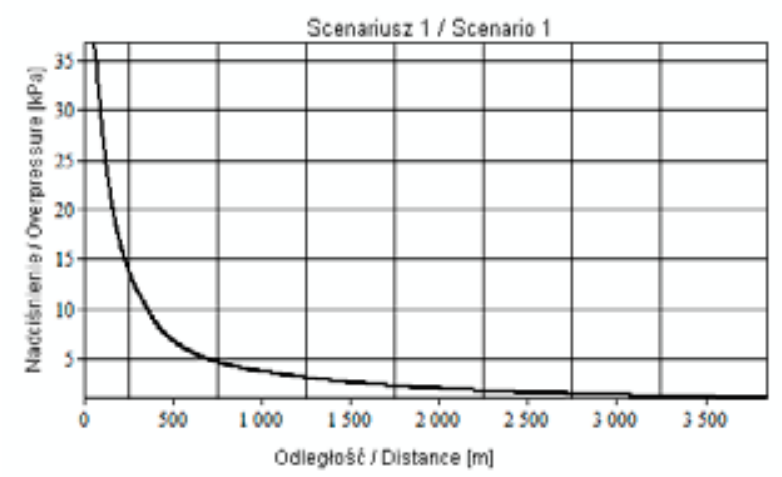

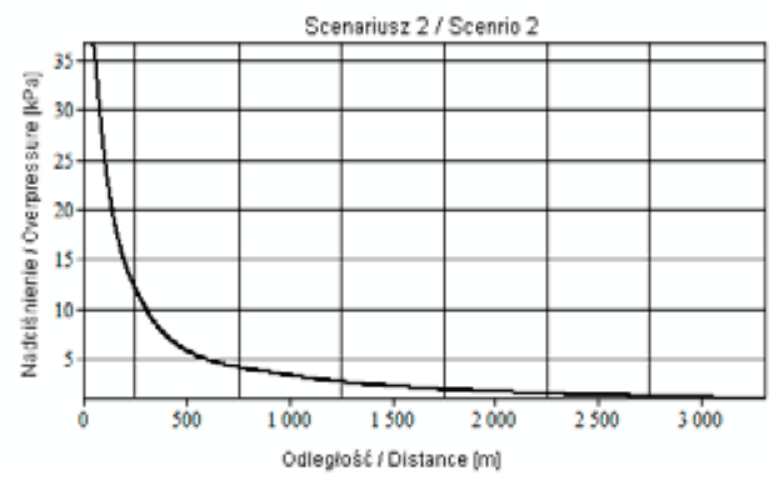

Ryc. 14. Zasięg działania minimalnego nadciśnienia rejestrowanego przez program RizEx $(1 \mathrm{kPa})$ od miejsca eksplozji propanu w Port Hudson.

Fig. 14. The operating range of overpressure (min. $1 \mathrm{kPa}$ ) generated by a propane explosion at Port Hudson

Źródło: Opracowanie własne. Source: Own elaboration.

Ponadto w programie wyznaczone zostały wartości masy TNT odpowiadające energii wybuchu. Dla przypomnienia wartości podane w raporcie oszacowano na 45-68 t TNT. Na podstawie założeń scenariusza 1, program RizEx-2 obliczył tę wartość na 84,5 t TNT, natomiast w przypadku scenariusza 2 - na 54 t TNT. 


\section{Podsumowanie}

Dokonano analizy możliwości odtworzenia sytuacji awaryjnej z wykorzystaniem programu RizEx-2 na podstawie zdarzenia, które miało miejsce w roku $1970 \mathrm{w}$ Port Hudson (USA), w celu zbadania zasadności użycia tego programu do przeprowadzania oceny skutków wypadków z udziałem gazów wybuchowych. Wykorzystano do tego trzy moduły programu: dwa dotyczące dyspersji gazu (Dispersion Gaussian Model - Neutral Gas, Formation of Explosion-Hazardous Cloud) oraz model wybuchu (Explosion). Uzyskane w programie RizEx-2 wyniki porównano $\mathrm{z}$ raportem sporządzonym bezpośrednio po zdarzeniu przez Amerykański Urząd Górnictwa. Ich porównanie przedstawiono w tabeli 4.

Tabela 4. Zestawienie wyników uzyskanych w programie RizEx-2 oraz danych opisanych w raporcie wykonanym przez Amerykański Urząd Górnictwa

Table 4. Summary of the results obtained in the RizEx-2 and the data described in the report made by the U.S. Bureau of Mines

\begin{tabular}{|c|c|c|c|}
\hline Parametr/Parameter & $\begin{array}{l}\text { Wyniki raportu / } \\
\text { The results of the report }\end{array}$ & $\begin{array}{c}\text { RizEx-2 } \\
\text { scenariusz } 1 \text { / } \\
\text { scenario } 1\end{array}$ & $\begin{array}{c}\text { RizEx-2 } \\
\text { scenariusz } 2 \text { / } \\
\text { scenario } 2\end{array}$ \\
\hline $\begin{array}{l}\text { Zasięg smugi / } \\
\text { Range of the trail }\end{array}$ & $\begin{array}{l}\text { Zasięg pewny / Sure range: } \\
\text { 230-267 m } \\
\text { Zasięg przypuszczalny / } \\
\text { Supposed range: } \\
438-460 \mathrm{~m}\end{array}$ & $302 \mathrm{~m}$ & $256 \mathrm{~m}$ \\
\hline $\begin{array}{l}\text { Szerokość smugi / } \\
\text { Width of the trail }\end{array}$ & $\begin{array}{c}\text { Zasięg pewny / Sure range: } \\
15-30 \mathrm{~m} \\
\text { Zasięg przypuszczalny/ } \\
\text { Supposed range: } \\
\text { 30-45 m }\end{array}$ & $33 \mathrm{~m}$ & $28 \mathrm{~m}$ \\
\hline $\begin{array}{c}\text { Masa propanu pomiędzy dolną a górną granicą } \\
\text { wybuchowości / } \\
\text { The mass of propane between the lower and the } \\
\text { upper explosion limit }\end{array}$ & $2877,8 \mathrm{~kg}$ & $4205 \mathrm{~kg}$ & $2683 \mathrm{~kg}$ \\
\hline $\begin{array}{l}\text { Zasięg nadciśnienia } 6,9 \mathrm{kPa} / \\
\text { Pressure range } 6.9 \mathrm{kPa}\end{array}$ & $600 \mathrm{~m}$ & $483 \mathrm{~m}$ & $428 \mathrm{~m}$ \\
\hline $\begin{array}{c}\text { Zasięg nadciśnienia } 3,4 \mathrm{kPa} / \\
\text { Pressure range } 3.4 \mathrm{kPa}\end{array}$ & $1025 \mathrm{~m}$ & $1104 \mathrm{~m}$ & $953 \mathrm{~m}$ \\
\hline $\begin{array}{c}\text { Masa TNT } \\
\text { odpowiadająca energii wybuchu / } \\
\text { The mass of TNT equivalent blast power }\end{array}$ & $45-68$ t TNT & $84,5 \mathrm{t} \mathrm{TNT}$ & $54 \mathrm{t} \mathrm{TNT}$ \\
\hline
\end{tabular}

Źródło: Opracowanie własne.

Source: Own elaboration.

$\mathrm{W}$ porównaniu z wynikami raportu sporządzonego bezpośrednio po awarii w Port Hudson (USA) przez Amerykański Urząd Górnictwa, symulacja w programie RizEx-2 w stopniu dobrym odwzorowuje to zdarzenie.

1. Obszar zajmowany przez mieszaninę propanu i powietrza wyznaczony przez program RizEx-2 jest zbliżony do wartości podanych jako „zasięg pewny” oraz „szerokość pewna” w raporcie i nie przekracza wartości „zasięgu przypuszczalnego” ani „szerokości przypuszczalnej”.

2. Masa propanu pomiędzy dolną a górną granicą wybuchowości wyznaczona w scenariuszu 2 jest zbliżona do wartości opisanej w raporcie, jednak to scenariusz 1 powinien był lepiej odwzorować tę wartość, ze względu na identyczną wartość prędkości wiatru.

3. Zakresy nadciśnienia otrzymane w RizEx-2 są spójne jedynie dla wartości $3,4 \mathrm{kPa}$, natomiast dla wartości
$6,9 \mathrm{kPa}$, są wyraźnie mniejsze. Dla scenariusza 1 różnica wynosi $117 \mathrm{~m}$, a dla scenariusza 2 - $172 \mathrm{~m}$ w porównaniu do wartości wynikającej z raportu, tj. $600 \mathrm{~m}$.

4. Wyznaczona masa TNT, która odpowiadałaby energii wybuchu, mieści się w zakresie podanym w raporcie jedynie dla scenariusza 2 . W przypadku scenariusza 1 przekracza ona znacznie te wartości.

5. Program RizEx nie uwzględnia kształtu terenu ani faktu, że propan jest gazem cięższym od powietrza. Stąd wynikać mogą rozbieżności i nieścisłości przy analizie zaistniałych zdarzeń awaryjnych. Przykładem tego jest błędna ocena zniszczeń budynku oznaczonego numerem 5 na mapie (ryc. 3), który według programu uległby jedynie nieznacznym uszkodzeniom. W raporcie wyraźnie udokumentowane zostały większe uszkodzenia, co jednoznacznie można stwierdzić na 
podstawie ryc. 6. Wynika to z faktu, że model Gaussa, który wykorzystywany jest przez RizEx-2 do obliczeń dyspersji, ma zastosowanie jedynie dla gazów o dodatnim i neutralnym współczynniku unoszenia. W związku z tym jego obliczenia dotyczące propanu, który jest cięższy od powietrza, są obarczone błędem.

6. Obszar między dolną a górną granicą wybuchowości wyznaczony przez program nie obejmował żadnego z obiektów na mapie, z czego można wnioskować, że budynek $\mathrm{z}$ chłodziarkami, na który wskazano w raporcie, nie mógłby stanowić skutecznego źródła zapłonu. Natomiast zgodnie $\mathrm{z}$ raportem propan ze względu na to, że jest gęstszy od powietrza oraz ze względu na słabe jego wymieszanie w związku ze słabym wiatrem, przemieszczałby się blisko nad ziemią. Dodatkowo z uwagi na to, że wspominany budynek znajdował się w dolinie, propan prawdopodobnie spłynąłby grawitacyjnie do tego miejsca, a następnie przedyfundował do wnętrza budynku i utworzył mieszankę o stężeniu wybuchowym. Jeszcze raz rozbieżności pomiędzy wynikami uzyskanymi z programy odbiegają od rzeczywistości w związku z tym, że program nie uwzględnił właściwości propanu oraz kształtu terenu.
7. Za pomocą programu nie można jednoznacznie ocenić, czy powstały wybuch nosił znamiona detonacji, ponieważ program nie wyznacza prędkości rozprzestrzeniania się fali ciśnienia ani prędkości spalania.

$\mathrm{Na}$ podstawie powyższych wnioskuje się, że program RizEx-2 może stanowić cenne narzędzie w analizie awarii $\mathrm{z}$ udziałem gazociągów oraz ich następstw. Jednakże należy uwzględnić ograniczenia programu i nie traktować otrzymanych wyników jako ostatecznych, a jako pomoc w interpretacji analizowanych zdarzeń. Dane wykorzystywane do obliczeń powinny być przede wszystkim uzyskane na podstawie dochodzenia ze zdarzenia, a wyniki programu zawsze ewaluowane w odniesieniu do rzeczywistych skutków.

Badanie zrealizowane $\mathrm{w}$ ramach projektu finansowanego przez Narodowe Centrum Badań i Rozwoju (NCBR) w ramach projektu nr DOB-BIO6/02/50/2014 pt. „Opracowanie metod neutralizacji zagrożenia wybuchu wytypowanych zbiorników z gazami technicznymi, w tym alternatywnymi źródłami zasilania w środowisku pożarowym na potrzeby ratowników biorących udział w akcjach ratowniczo-gaśniczych”.

\section{Literatura}

[1] Pipeline Incident 20 Year Trends [dok. elektr.], http://www. phmsa.dot.gov/pipeline/library/datastatistics/pipelineincidenttrends, [Dostęp: 05.03.2015].

[2] Burgess D.S., Zabetakis M.G., Detonation of a flammable cloud following a propane pipeline break, Bureau of Mines, USA 1973.

[3] Saleev E., Raschetnyy metod otsenki granits zon razrusheniy pri vzryve gazoparovozdushnykh smesey, "Pozhary i chrezvychajnye situacii: predotvrashhenie, likvidacija" Issue 3, 2011, pp. 17-20.

[4] Mannan S., Lees' Loss Prevention in the Process Industries, Elsevier, 2012.

[5] Software Complex "RizEx-2" Description of Applied Analysis and Calculation Methods, Scientific Center Of Risk Investigations “Rizikon”, Severodonetsk 2006.

[6] Expert Simulation Tools for Industrial Accidents and Risk Assessment "RizEx-2". User’s Manual., Scientific Center Of Risk Investigations “Rizikon”, Severodonetsk 2006.

[7] User's Manual (Functional Description) Of The Research Software Complex Of Risk Assessment And Accident Simulation "RizEx-2", Scientific Center Of Risk Investigations “Rizikon”, Severodonetsk 2011.

mgr inż. Anna Dziechciarz w 2012 r. uzyskała dyplom inż. technologii chemicznej na Wydziale Technologii Chemicznej Politechniki Poznańskiej, a w 2013 dyplom mgr inż. inżynierii chemicznej tejże uczelni. Obecnie pracuje na stanowisku młodszego specjalisty w Zespole Laboratoriów Procesów Spalania i Wybuchowości w Centrum Naukowo-Badawczym Ochrony Przeciwpożarowej - PIB w Józefowie.

mł. bryg. inż. Piotr Lesiak w 2002 r. ukończył studia w Szkole Głównej Służby Pożarniczej w Warszawie. Absolwent studiów inżynierskich na kierunku chemia w Wojskowej Akademii Technicznej. Pełni służbę w Centrum Naukowo-Badawczym Ochrony Przeciwpożarowej PIB w Józefowie, na stanowisku starszego specjalisty w Zespole Laboratoriów Procesów Spalania i Wybuchowości.

inż. Damian Bąk w roku 2013 ukończył studia na Wydziale Inżynierii Produkcji Politechniki Warszawskiej. Obecnie pracuje na stanowisku młodszego specjalisty w Zespole Laboratoriów Procesów Spalania i Wybuchowości w Centrum Naukowo-Badawczym Ochrony Przeciwpożarowej - PIB w Józefowie. 